\title{
Trend Analysis of Daily Maximum Rainfall Series in Çoruh Basin, Turkey
}

\author{
Fatih TOSUNOĞLU ${ }^{1}$
}

\begin{abstract}
In the present study, trends of daily maximum rainfall series in three time scales including annual, seasonal and monthly time series were investigated by using Mann-Kendall (MK), modified Mann-Kendall (mMK), Theil-Sen (TH) and Sequential Mann-Kendall (SMK) trend tests. These tests are applied to daily maximum rainfall data of five stations located Çoruh Basin, Turkey. The MK and mMK tests are employed to quantify significance of the trend, the TH test is used to determine magnitude of the trend and the SMK test is also applied for defining starting year of the significant trend. The results of the MK and $\mathrm{mMK}$ tests showed that there are considerable significant increasing trends of daily maximum rainfalls in months including January, March, July, August and October. However, significant decreasing trends were detected in daily maximum rainfalls of May and December. In annual and seasonal time scale, significant increasing trends were detected. The TH test also indicated that the highest magnitude of the negative trends was occurred in daily maximum rainfalls of December while the highest magnitude of the positive trends was found in daily maximum rainfalls of annual time scale. Furthermore, the SMK test revealed that the significant positive and negative trends mostly began in the mid-1980s and the early 1990s.
\end{abstract}

Keywords: Çoruh basin, daily maximum rainfalls, mann-kendall test, modified mann-kendall test, sequential mann-kendall test, theil-sen test

\section{Çoruh Havza'sındaki Günlük Maksimum Yağış Serilerinin Trend Analizi}

ÖZET: Bu çalışmada, yıllık, mevsimlik ve aylık üç zaman dilimdeki günlük maksimum yağışların trendleri Mann-Kendall (MK), modifiye edilmiş Mann-Kendall (mMK), Theil-Sen (TH) ve Mann-Kendall Sıra Korelasyon (MKSK) testleri kullanılarak araştırılmıştır. Bu testler, Çoruh havzasında bulunan 5 adet istasyonun günlük maksimum yağış verilerine uygulanmıştır. MK ve mMK testleri trendlerin anlamlılığını belirlemede, TH testi trendin büyüklüğünü hesaplamada ve MKSK testi ise ele alınan verilerdeki anlamlı trendlerin başladığı yılları tespit etmede kullanılmıştır. MK ve mMK test sonuçlarına göre Ocak, Mart, Temmuz, Ağustos ve Ekim aylarına ait günlük maksimum yağış değerlerinde istatistiksel anlamda bir artış varken Mayıs ve Aralık aylarının günlük maksimum yağış verilerinde ise istatistiki anlamda önemli azalışlar söz konusudur. Yılllık ve mevsimlik zaman ölçeğinde ise ele alınan verilerde istatistiksel anlamlı artış trendleri tespit edilmiştir. Ayrıca, TH testi günlük maksimum yağışlardaki en büyük negatif (azalış) trendin Aralık ayında, en büyük pozitif (artışın) trendin ise yıllık zaman diliminde meydana geldiğini belirtmektedir. Buna ek olarak, MKSK testide bu tespit edilen anlamlı negatif ve pozitif trendlerin başlangıç yıllarının çoğunlukla 1980'lerin ortalarında ve 1990'ların başları olduğunu göstermektedir.

Anahtar Kelimeler: Çoruh havzası, günlük maksimum yağışlar, mann-kendall testi, mann-kendall sıra korelasyon testi, modifiye edilmiş mann-kendall testi, theil-sen testi

Erzurum Teknik Üniversitesi, Mühendislik-Mimarlık Fakültesi, İnşaat Mühendisliği Bölümü, Erzurum, Türkiye

Sorumlu yazar/Corresponding Author: Fatih TOSUNOĞLU, ftosunoglu@erzurum.edu.tr 


\section{INTRODUCTION}

Rainfall data is one of the most important variables used in hydrological science. Changes in rainfall data have crucial effects on various types of water resources problems, such as floods and droughts. Therefore, spatial and temporal trend assessment of rainfalls play important role for water resources designer and decision makers in a region. A number of studies conducted to detect spatial and temporal changes of rainfalls in many countries and regions. For this purpose, various statistical techniques have been defined and employed by researches. A brief review of these techniques (Khaliq et al., 2009; Sonali and Kumar, 2013) have demonstrated that parametric and non-parametric methods have been widely employed to detect significant trends in hydro-meteorological data. Among these, the Mann-Kendall test is one of the most widely used nonparametric method for detecting significant monotonic trends in rainfall time series. However, the Mann-Kendall test is not able to provide an estimate of trend magnitude and thus, Theil-Sen approach, which is another nonparametric method, is commonly used for quantifying the magnitude of the trend. Furthermore, to define the beginning of significant trend over time is also important case in trend detection studies. To achieve this aim, Sequential Mann-Kendall test, which is an extension of Mann-Kendall test, is usually used as powerful tool in literature. In Turkey, numerous efforts have been made in the past to detect trends in the hydro-meteorological variables (such as rainfall, streamflow, temperature, etc.). For instance, Turkes et al. (1995) investigated trends in the long-term annual mean air temperatures obtained from 85 climate stations in Turkey. They utilized four statistical tests and it was found that regional mean temperatures tend to be warmer in eastern Anatolia while the temperatures in the Marmara and Mediterranean regions tend to be cooler (some more temperature studies; Karaca et al., 1995; Kadioglu, 1997; Tayanc et al., 1997; Tecer and Cerit, 2009; Toros, 2012). Turkes (1996) studied trends in annual rainfall records from 91 stations uniformly distributed across Turkey in the period 1930-1993 and Mann-Kendall tests have pointed to significant decreasing trends in the rainfall series of Black Sea and Mediterranean regions (some more rainfall studies; Partal and Kahya, 2006; Turkes et al., 2009; Acar and Senocak, 2012; Ay and Kisi, 2015). Kahya and Kalayci (2004) searched trends in monthly streamflow data obtained from 26 basins over Turkey and applied four non-parametric trend tests namely the Sen's T, the Spearman's Rho, the Mann-Kendall, and the Seasonal Kendall. The test results showed that there were significant decreasing trends for streamflows located in the regions of western and southeastern Turkey. (some more streamfow studies; Cigizoglu et al., 2005; Topaloglu, 2006; Yenigun et al., 2008; Şen, 2012; Saplioglu et al., 2014). The majority of the studies mentioned above have employed the annual mean or monthly mean data for trend analyses. However, a limited number of works on trend detection in maximum daily rainfall data have been reported in literature. Also, to the best knowledge of the author, there is not any published work in the literature related to application of trend tests to these variables in Çoruh basin where a number of water resources structures have been recently constructed or are under construction. Therefore, the purpose of the present study is to investigate the existing trends in daily maximum rainfalls for three time scales including annual, seasonal and monthly time series in Çoruh basin, Turkey. To achieve this aim, Mann-Kendall and modified Mann-Kendall tests are applied to detect monotonic trends, Theil-Sen is employed to quantify the magnitude of the trends and Sequential Mann-Kendall test is then used for defining the beginning time of significant trends in rainfall series.

\section{MATERIAL AND METHODS}

Çoruh basin, which is located in the northeast of Turkey, was selected as study area in this study. The basin covers an area of $19.748 \mathrm{~km}^{2}$, which covers approximately $2.53 \%$ of Turkey. The mean annual rainfall for this basin is about $480 \mathrm{~mm}$ and terrain elevations in the basin, with reference to mean sea level, range from 30 to $2200 \mathrm{~m}$ (Yerdelen et al., 2010). The basin has gained more economic importance for Turkey as a number of the new water resources structures (dams and hydroelectric power plants) have been recently completed, or are already under construction. Therefore, any case study related to investigate changes in hydrometeorological variables (especially rainfalls) is much more important now for water resources planners in the basin. In this study, daily maximum rainfall records of five meteorological stations (Bayburt, Ispir, Oltu, Tortum and Artvin) located in the basin were used for trend analyses. The location map of the study area and the stations used are given in Figure 1. 


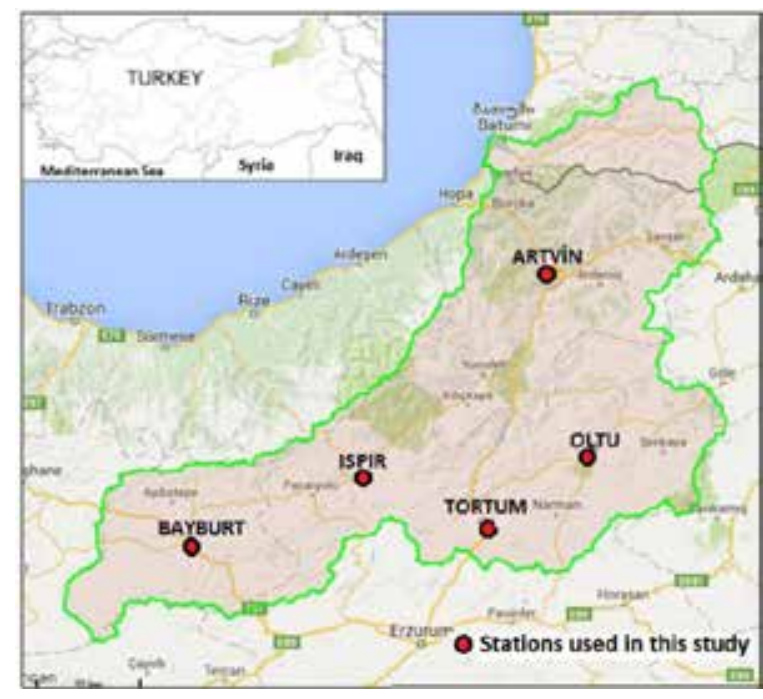

Figure 1. The study area and location of the stations

The daily rainfall records were provided by the Turkish State Meteorological Service for the period 1981-2011 (only for Oltu) and 1970-2011 (for others).

These data were also grouped into different seasons; winter (December-February), spring (MarchMay), summer (June-August) and fall (SeptemberNovember).

As well as annual and monthly daily maximum rainfall, seasonal daily maximum rainfall were calculated from daily observations.

In this study, four statistical methods are used to analyze trends of rainfall series.

\section{Mann-Kendall trend test}

The Mann-Kendall test, which was originally developed by Mann (1945) and the test-statistic distribution was subsequently derived by Kendall (1975), is a rank-based non-parametric test for detecting a monotonic trend in a time series. Hydro-meteorological data (such rainfall, streamflow, temperature etc.) generally have a skewed distribution, it is more suitable to nonparametric methods than parametric methods for trend detection. Therefore, the Mann-Kendall have been widely used to evaluate the statistical significance of trends in these data series (Onoz and Bayazit, 2003; Modarres and da Silva, 2007; Kumar et al., 2010). The test statistics ( $\mathrm{S}$ ) is calculated as;

$$
\begin{aligned}
& \operatorname{sign}\left(x_{j}-x_{i}\right)=\left\{\begin{array}{cc}
1 ; & \text { if } x_{j}>x_{i} \\
0 ; & \text { if } x_{j}=x_{i} \\
-1 ; & \text { if } x_{j}<x_{i}
\end{array}\right. \\
& S=\sum_{i=1}^{n-1} \sum_{j=i+1}^{n} \operatorname{sign}\left(x_{j}-x_{i}\right)
\end{aligned}
$$

In Eq.(2), $\mathrm{n}$ denotes the length of the data set and $x_{i}$ and $x_{j}$ are the data values at times $i$ and $\mathrm{j}$. While positive values of the test statistics (S) show an increasing trend, negative values indicates an decreasing trends (Ay and Kisi, 2015). Then, following steps are employed to evaluate the statistical significance of trend;

a- The null hypothesis $\left(\mathrm{H}_{0}\right)$ is assumed that data are independent and identically distributed random variables (no trend is present), while the alternative hypothesis $\left(\mathrm{H}_{1}\right)$ indicates a statistical significant trend. 
If $\mathrm{n}<10$, the value of $|\mathrm{S}|$ is compared directly to the theoretical distribution of $\mathrm{S}$ derived by Mann and Kendall b- If $\mathrm{N}>10$, the statistic $\mathrm{S}$ is expected to be normal distribution with a mean of zero and variance which is calculated by

$$
\operatorname{Var}(S)=\frac{n(n-1)(2 n+5)-\sum_{i=1}^{P} t_{i}\left(t_{i}-1\right)\left(2 t_{i}+5\right)}{18}
$$

where $\mathrm{P}$ is the number of tied groups and the summary sign $\left(\sum\right)$ indicates the summation over all tied groups and $t_{i}$ is the number of data in the $\mathrm{i}^{\text {th }}$ (tied) group.

$$
Z=\left\{\begin{array}{cl}
\frac{S-1}{\sqrt{\operatorname{Var}(S)} ;} & \text { if } S>0 \\
0 ; & \text { if } S=0 \\
\frac{S+1}{\sqrt{\operatorname{Var}(S)} ;} & \text { if } S<0
\end{array}\right.
$$

If the calculated $\mathrm{Z}$ value is greater than the critical value of the standard normal distribution at the significance level of $\alpha$, null hypothesis $\left(\mathrm{H}_{0}\right)$ should be rejected and it implies that there is a statistically significant positive or negative trend in the data series. According to Yue and Wang (2004), the Mann-Kendall test requires data under consideration to be randomly distributed. However,

$$
-1.645 / \sqrt{N}<r_{1}<+1.645 / \sqrt{N}
$$

in which denotes the lag- 1 autocorrelation coefficient and $\mathrm{n}$ indicates the number of observation in the data. If computed falls inside the above confidence interval at the 0.10 level of significance, the data series are assumed to be independent variables, otherwise the data series exhibit serial correlation. Based on Eq. (5), if a significant autocorrelation is
If data series do not have tied groups, this summation term is excluded from the equation. After, the standard $\mathrm{Z}$ value of the test statistics is calculated by; hydro-meteorological time series usually exhibit statistically significant serial correlation which can have an effect the power of the test. Therefore, before applying the test, serial correlation structure should be checked. To check significance of serial correlation at $90 \%$ confidence intervals, the following equation can be used detected in data series, it would be more useful to apply modified version of the test statistic. In this study, we used the modified Mann-Kendall test which was introduced by Hamed and Rao (1998), to analyze trends in serial correlated data series. Variance of the modified Mann-Kendall trend test is computed as;

$$
\operatorname{Var}(S)=\frac{n(n-1)(2 n+5)}{18}\left[1+\frac{2}{n(n-1)(n-2)} \sum_{k=1}^{n-1}(n-k)(n-k-2) r_{k}\right]
$$


In this equation, $r_{k}$ denotes the autocorrelation coefficient at lag $\mathrm{k}$.

\section{Theil-Sen trend test}

In order to quantify the magnitude of the trend in

$$
M=\operatorname{median} \frac{x_{j}-x_{i}}{j-i}
$$

Where $x_{j}$ and $x_{i}$ are the data values at times $j$ and $i(j>i)$, respectively. The positive value of the $\mathrm{M}$ demonstrates the slope of the increasing trend and negative value for the decreasing trend.

\section{Sequential Mann-Kendall trend test}

In this study, Sequential Mann-Kendall (SMK) test,

a-The values of original data series, $(j=1, \ldots$ $, n)$ are compared with $(i=1, \ldots \ldots \ldots, j-1)$. The number of cases $>$ is then counted for each comparison and data series, Theil-Sen test, which was proposed by Sen (1968), is commonly used in hydrological and meteorological studies. According to this method, the trend magnitude can be calculated as follows;

which was introduced by Sneyers (1990), is employed to detect the beginning of any significant change in the rainfall series.

In the SMK test, sequential progressive series $\mathrm{u}(\mathrm{t})$ and retrograde series $\mathrm{u}^{\prime}(\mathrm{t})$ are estimated using the following steps;

indicated by $n_{j}$.

$b$ - The test statistics $t_{j}$, the mean and variance of the test statistics are computed by equations

$$
t_{j}=\sum_{1}^{j} n_{j}, \quad E(t)=\frac{n(n-1)}{4}, \operatorname{Var}\left(t_{j}\right)=\frac{[j(j-1)(2 j+5)]}{72}
$$

c- The sequential progressive series $u(t)$ are then calculated as

$$
u(t)=\frac{t_{j}-E(t)}{\sqrt{\operatorname{Var}\left(t_{j}\right)}}
$$

Similar to the calculation of progressive series $\mathrm{u}(\mathrm{t})$, retrograde series $u^{\prime}(t)$ are computed backwards starting from the end of the data series. Negative values of $u(t)$ or $\mathrm{u}^{\prime}(\mathrm{t})$ indicate a downward trend while positive values show an upward trend in the data series. To define any significant change, the values of $\mathrm{u}(\mathrm{t})$ and $\mathrm{u}^{\prime}(\mathrm{t})$ are plotted against time and the intersection point of these curves provides the approximate year at that time the trend begins. If $u(t)$ or $u^{\prime}(t)$ curves exceed certain limits before or after this intersection point, it implies that there is a statistically significant trend (Nasri and Modarres, 2009; Rashid et al., 2015). 


\section{RESULTS AND DISCUSSION}

\section{Mann-Kendall and modified Mann-Kendall test results}

Before applying the Mann-Kendall test, lag-1 serial autocorrelation coefficients were computed for maximum daily rainfall series in monthly, seasonal and annual time scales. The computed lag1 autocorrelations are shown in Figure 2. The 90\% confidence limits were calculated by using Eq.5 and these limits are also represented in the graphs. According to these graphs, most of autocorrelation coefficients are found within these confidence levels indicating the daily maximum series are independent variables. However, there are a few cases in which the autocorrelation coefficients placed outside the confidence bands implying that the presence of serial correlation. Therefore, in this part of the study, as well as Mann-Kendall (MK) test, modified Mann-Kendall (mMK) test was applied to examine significance of trend in seventeen daily maximum rainfall variables (i.e. one annual, four seasonal and 12 monthly). The results of the $\mathrm{MK}$ and $\mathrm{mMK}$ tests are summarized in Table 1 and Figure 3. $90 \%\left(\alpha=0.1\right.$ and $\left.Z_{\alpha}=1.64\right)$ and $95 \%\left(\alpha= \pm 0.05\right.$ and $\left.Z_{\alpha}= \pm 1.96\right)$ of level are used to check significance of increasing and decreasing trends.
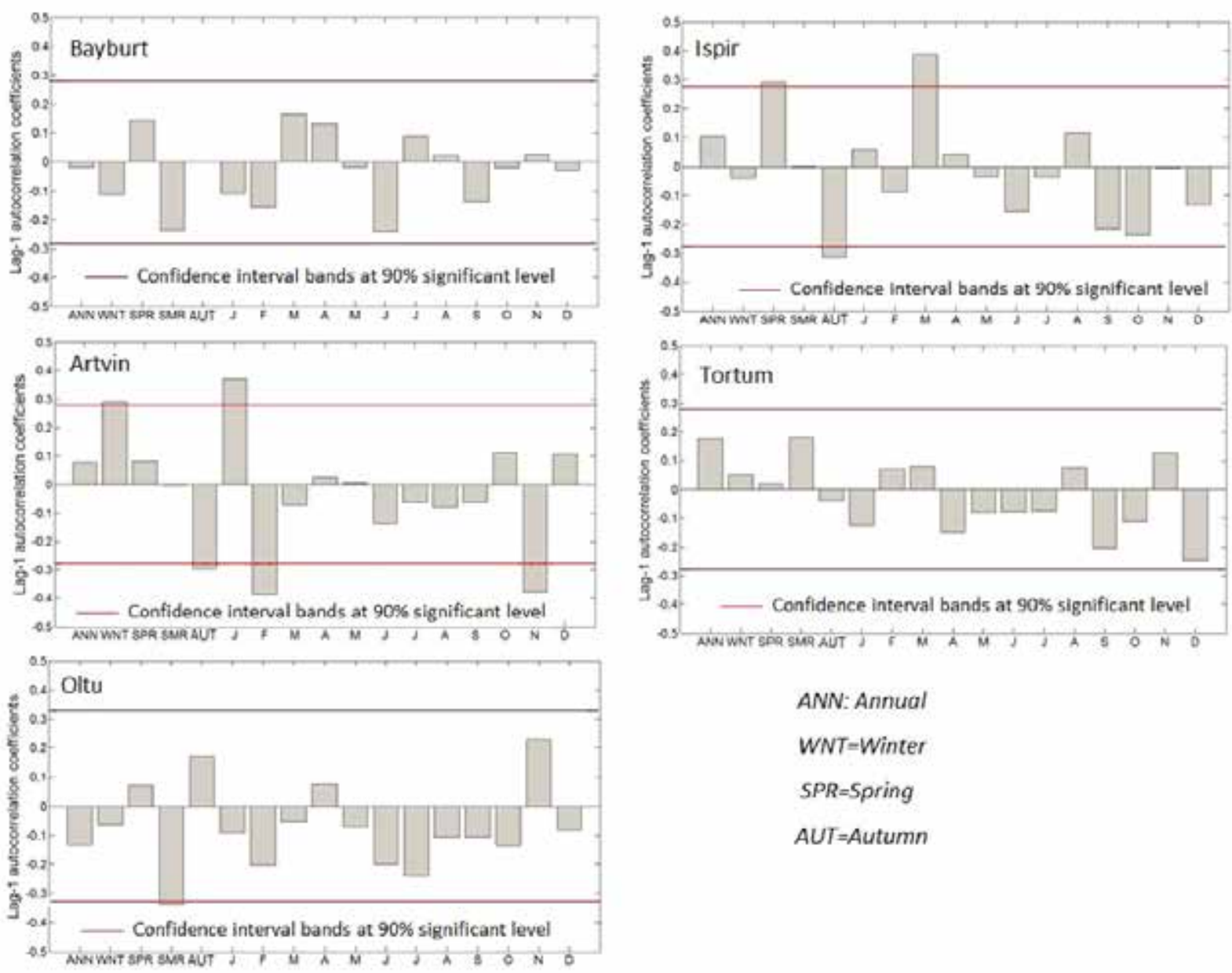

ANN: Annual
WNT=Winter
SPR=Spring
AUT $=$ Autumn

Figure 2. Lag-1 autocorrelation coefficients for the daily maximum rainfall variables (annual, seasonal and monthly) for the stations

Table 1 represents the calculated $\mathrm{Z}$ values of MK and modified MK tests at annual and seasonal time scale. Based on the results of the tables at annual time scale, it can be inferred that a significant increasing trend was occurred only for Ispir station although the daily maximum rainfall data tend to increase for all stations. In the seasonal time scale, MK test and the modified MK tests pointed out Bayburt, Ispir and Tortum stations with significant increasing trends existence in autumn, summer and spring, respectively. 
Table 1. The results of MK and modified MK tests for daily maximum rainfalls in annual and seasonal time scale The values in brackets demonstrate the $\mathrm{Z}$ value of modified MK test

\begin{tabular}{llccccc}
\hline \multirow{2}{*}{$\begin{array}{l}\text { Station } \\
\text { Name }\end{array}$} & $\begin{array}{l}\text { Obsv. } \\
\text { Period }\end{array}$ & \multicolumn{5}{c}{ Calculated Z values } \\
\cline { 2 - 7 } & & \multicolumn{1}{c}{ ANN } & WNT & \multicolumn{1}{c}{ SPR } & \multicolumn{1}{c}{ SMR } & AUT \\
\hline Bayburt & $1970-2011$ & $1.59(1.59)$ & $0.75(0.99)$ & $-0.27(-0.21)$ & $0.64(0.64)$ & $\mathbf{1 . 7 3}(\mathbf{1 . 7 3})$ \\
\hline Ispir & $1970-2011$ & $\mathbf{2 . 2 7}(\mathbf{2 . 8 8})$ & $-0.60(-0.60)$ & $1.05(1.42)$ & $\mathbf{1 . 7 8 ( 2 . 6 1 )}$ & $1.15(1.13)$ \\
\hline Tortum & $1970-2011$ & $1.33(1.61)$ & $-1.12(-1.12)$ & $\mathbf{2 . 1 6 ( 2 . 1 6 )}$ & $-0.01(-0.01)$ & $0.24(0.90)$ \\
\hline Oltu & $1981-2011$ & $0.58(0.58)$ & $-0.16(-0.26)$ & $0.83(0.83)$ & $0.51(0.59)$ & $-0.29(-0.36)$ \\
\hline Artvin & $1970-2011$ & $0.68(0.72)$ & $-0.66(-1.15)$ & $-0.57(-0.57)$ & $1.55(1.55)$ & $0.98(0.98)$ \\
\hline
\end{tabular}

Figure 3 displays the trend tests results in monthly time scale. In these figures, bubble maps that are provided by ArcGIS program are also used to describe magnitude of the computed $Z$ values. As can be seen from Figure 3, significant positive trends for Bayburt station were observed for daily maximum rainfalls of January, July and October. For Ispir station, the tests indicated significant positive trends for daily maximum rainfalls of March, July and October.

For Artvin station, significant positive trends were appeared for daily maximum rainfalls of July, August and October while significant decreasing (negative) trends were occurred for daily maximum rainfalls of May and December. Moreover, no significant trends were detected by $\mathrm{MK}$ and modified MK tests for Tortum and Oltu stations.

\section{Theil-Sen trend test results}

In this part of the study, Theil-Sen trend test was employed to determine magnitude of the trends in the data series. The magnitudes of the seventeen daily maximum rainfall variables (one annual, four seasonal and 12 monthly) have been calculated using Eq. 7 and the test results are given Table 3. In the table, we used the asterisk symbol (“*”) that provides the significant positive and negative trends obtained by the MK and mMK tests.As can be seen from the table, the trend magnitude changes associated with considered time scale and parts of the study region.
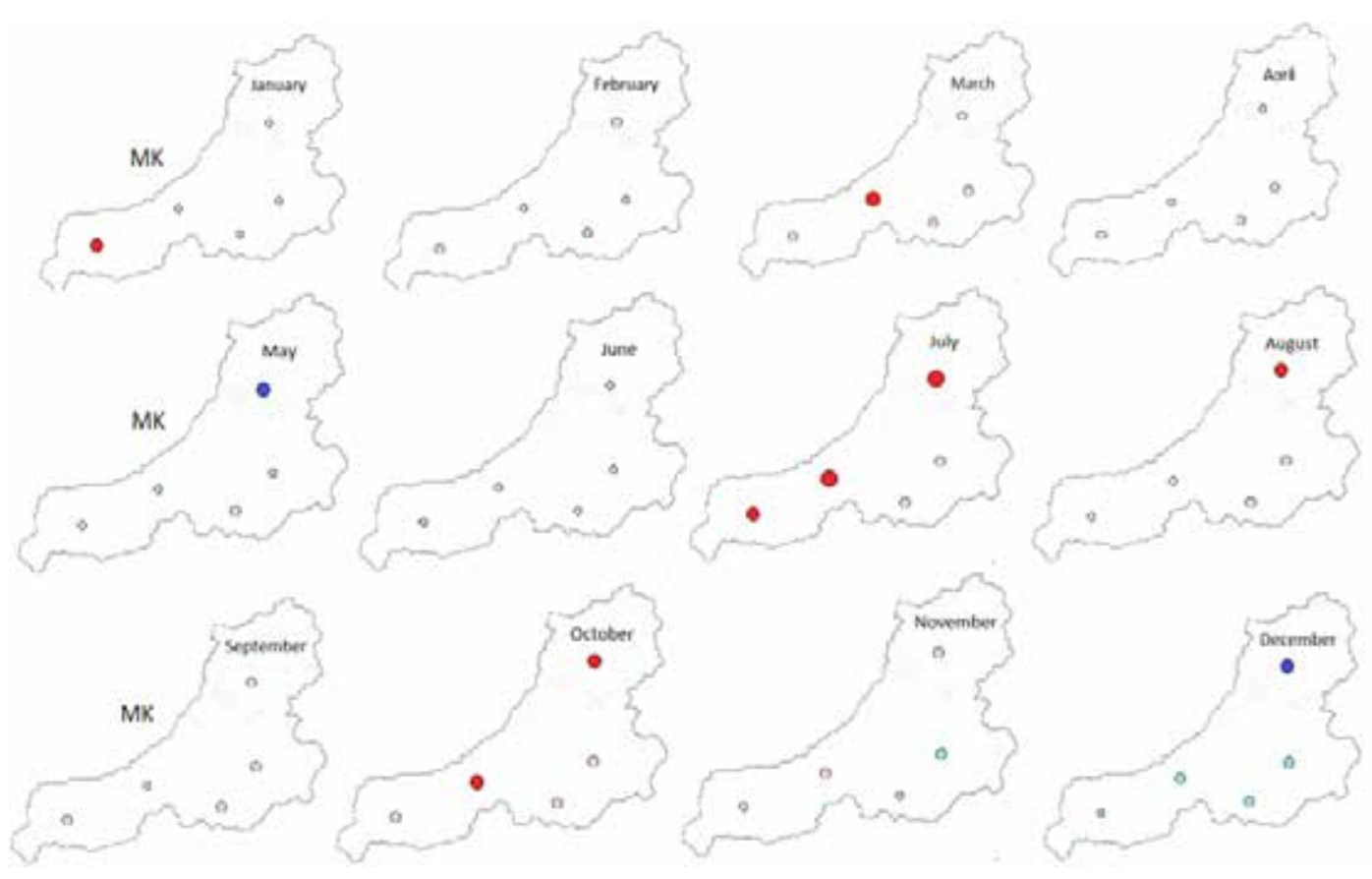

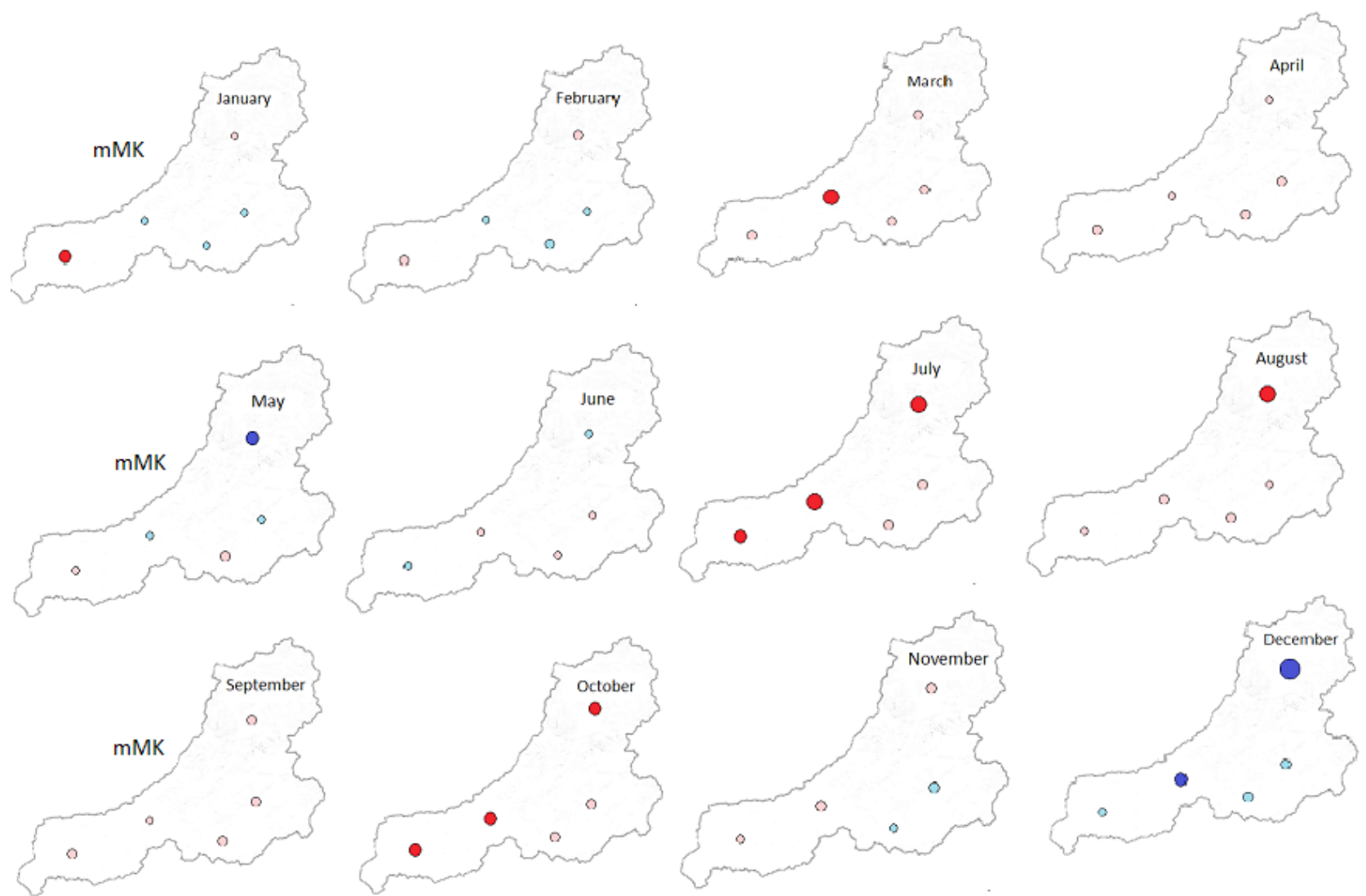

\section{$Z$ values of $M K$ and $m M K$ tests}
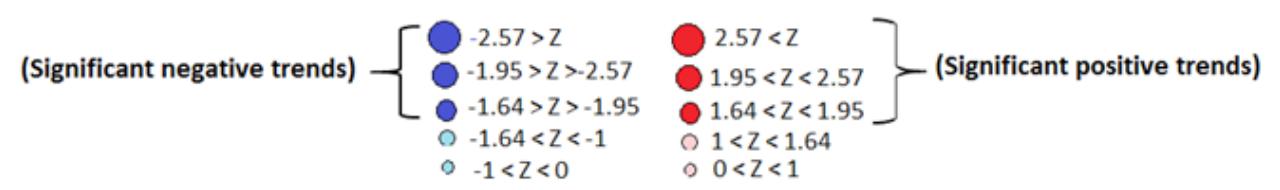

Figure 3. MK test and mMK test results for daily maximum rainfalls in monthly time scale

For example, in annual and seasonal time scale, the magnitude of trends varies from $0.07 \mathrm{~mm}_{\text {year }}{ }^{-1}$ to $0.24 \mathrm{~mm}$ year $^{-1}$ and from $-0.13 \mathrm{~mm}$ year ${ }^{-1}$ to 0.21 $\mathrm{mm}$ year $^{-1}$, respectively. Moreover, in monthly time scale, the computed magnitude of trends varies from $-0.36 \mathrm{~mm}$ year ${ }^{-1}$ to $0.21 \mathrm{~mm}$ year ${ }^{-1}$. Highest significant decrease was observed in daily maximum rainfalls of December for Artvin station while highest significant increase was noticed in daily maximum rainfalls of July for Ispir station.

\section{Sequential Mann-Kendall (SMK) trend test results}

Sequential Mann-Kendall trend test was applied to identify abrupt change point that indicates starting year of the trend in the data series. For this purpose, the SMK test applied the data series that show significant increasing or decreasing trends. As described in previous section, sequential progressive series $u(t)$ and retrograde series $u^{\prime}(t)$ were calculated for the maximum rainfall data considered. The computed $u(t)$ and $\mathrm{u}^{\prime}(\mathrm{t})$ values are depicted respectively by solid and dashed lines in Figure 4.In the Figure 4, Horizontal red dashed lines demonstrate confidence limits at the 5\% significance level. Here, due to constrain the paper's length, six examples of the SMK test plots are only given. Taking the plots of $u(t)$ and $u^{\prime}(t)$ of the Tortum station as an example, an abrupt increasing trend shift of daily maximum rainfall series in spring began around 1992 and becomes significant in about 2002 in which the $\mathrm{u}(\mathrm{t})$ is placed outside the $95 \%$ confidence bands. For maximum daily rainfalls of July of Artvin station, an abrupt positive change begins in 1985 and becomes statistically significant just after 2010 . 
Table 3. Magnitude of the trends obtained from Theil-Sen test for daily maximum rainfalls in annual, seasonal and monthly time scale

\begin{tabular}{|c|c|c|c|c|c|}
\hline Rainfall variables & Bayburt & Ispir & Tortum & Oltu & Artvin \\
\hline January & $0.15^{*}$ & -0.03 & -0.07 & -0.04 & 0.11 \\
\hline February & 0.05 & -0.06 & -0.11 & -0.01 & 0.15 \\
\hline March & 0.07 & $0.16^{*}$ & 0.13 & 0.15 & 0.15 \\
\hline April & 0.06 & -0.05 & 0.10 & 0.08 & 0.00 \\
\hline May & 0.04 & 0.00 & 0.07 & 0.10 & $-0.14 *$ \\
\hline June & -0.07 & 0.02 & 0.09 & 0.01 & -0.04 \\
\hline July & $0.20^{*}$ & $0.21^{*}$ & 0.11 & 0.16 & $0.17^{*}$ \\
\hline August & 0.00 & 0.05 & 0.09 & 0.01 & $0.19^{*}$ \\
\hline September & 0.12 & 0.00 & 0.02 & 0.04 & -0.01 \\
\hline October & $0.14^{*}$ & 0.14 & -0.06 & -0.07 & $0.20^{*}$ \\
\hline November & -0.03 & 0.08 & -0.02 & -0.18 & 0.19 \\
\hline December & -0.01 & $-0.15^{*}$ & -0.09 & 0.01 & $-0.36^{*}$ \\
\hline Winter & 0.06 & -0.06 & -0.10 & -0.02 & -0.13 \\
\hline Spring & -0.02 & 0.06 & $0.21 *$ & 0.10 & -0.05 \\
\hline Summer & 0.06 & $0.16^{*}$ & 0.00 & 0.09 & 0.12 \\
\hline Autumn & $0.20 *$ & 0.14 & 0.01 & -0.05 & 0.18 \\
\hline Annual & 0.14 & $0.24 *$ & 0.11 & 0.07 & 0.13 \\
\hline
\end{tabular}

*indicates the significant trends that obtained from the MK and mMK tests

For maximum daily rainfalls of July of Ispir station, an abrupt positive change is observed around the year 1975 and becomes statistically significant just after 2010 .

For maximum daily rainfalls of March at same station, there is an abrupt increasing change in 1990 and reaches statistically significance around 2007 which continues to the present time.

For maximum daily rainfalls of December at Artvin station, trend start to decrease around 1987 and it is found to be statistically significant after
2010. Moreover, there are multiple intersection points for maximum daily rainfall of Ispir station in annual scale.

In first intersection point, the rainfall data start to increase around 1975 and this trend becomes significant only for a short time period 1978-1981. Second changing point with an increase appears in around 1983 and this trend becomes significant from 1985 to 2002. Last abrupt increasing change is occurred in around 2003 and becomes significant around 2005 till present time. 

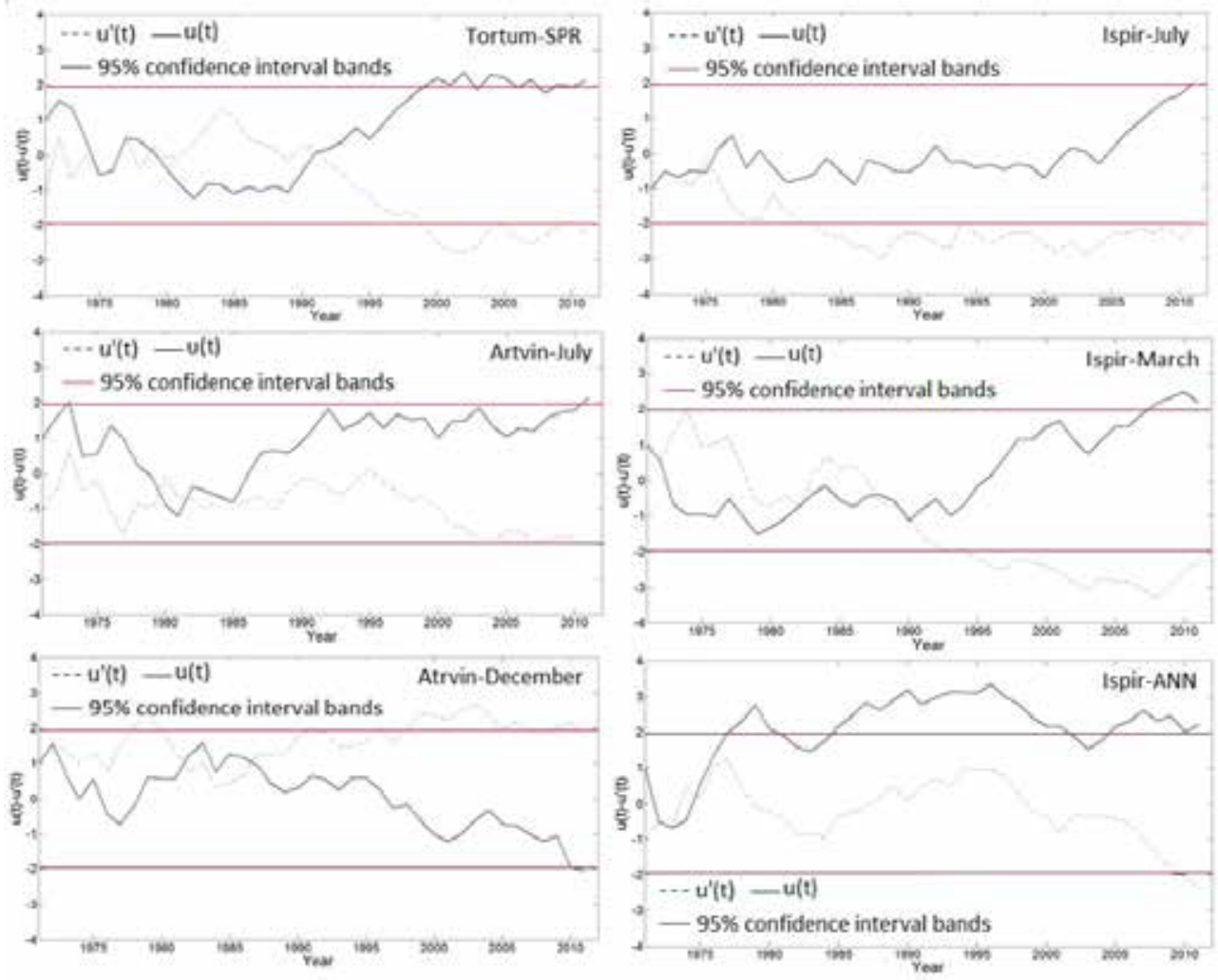

Figure 4. Graphical representation of the forward, $u(t)$ and the backward, $u^{\prime}(t)$ series of the Sequential Mann-Kendall for various daily maximum rainfall series

\section{CONCLUSION}

The present study aimed to investigate the existence of trends in daily maximum rainfalls of Çoruh Basin, Turkey using the Mann-Kendall (MK) with the modified Mann-Kendall (mMK), the TheilSen (TH) and the Sequential Mann-Kendall (SMK) trends tests. The following conclusions can be drawn from this study;

1- According to the MK and mMK tests, significant increasing trends were detected in months including January, March, July, August and October while significant decreasing trends were only occurred in May and December. For seasonal trend evaluation, no significant decreasing trend was detected. Moreover, the significant increasing trends were found in Autumn, Summer and Spring seasons for the Bayburt, Ispir and Tortum stations, respectively. Also, the significant positive trends were detected in annual time series of Ispir station. Furthermore, neither significant positive or negative trends were detected in the annual and seasonal time series of Oltu and Artvin stations.
2- Based on findings of the TH test, in the monthly series, the highest magnitude of the significant increasing trend was observed in July of Ispir station while the highest decreasing trend was found in December of Artvin station. In seasonal series, there were considerable significant increasing trend magnitudes in Spring and Summer seasons for Tortum and Ispir stations, respectively. Furthermore, only significant positive trend with the magnitude of 0.24 $\mathrm{mm}$ year ${ }^{-1}$ was detected in annual series at Ispir station.

3- According the results of the SMK test, in 1975, 1985 and 1990 showed the significant positive trend change point in the considered rainfall time series for July (for Ispir and Artvin), and March (for Ispir) respectively. Also, the positive significant change point began in 1992 in spring time at Tortum station. Moreover, the negative significant change point started in 1987 in daily maximum rainfalls of December of Artvin station.

\section{ACKNOWLEDGMENTS}

The author sincerely thanks to the Turkish State Meteorological Service for providing the daily rainfall data used in the study. 


\section{REFERENCES}

Acar R, Senocak S, 2012. Annual extreme precipitation trends for western Turkey in associated with north Atlantic oscillation (NAO) index. Energy Education Science and Technology Part a-Energy Science and Research, 29(1): 475-486.

Ay M, Kisi O, 2015. Investigation of trend analysis of monthly total precipitation by an innovative method. Theoretical and Applied Climatology, 120(3-4): 617-629.

Cigizoglu HK, Bayazit M, Onoz B, 2005. Trends in the maximum, mean, and low flows of Turkish rivers. Journal of Hydrometeorology, 6(3): 280-290.

Hamed KH, Rao AR, 1998. A modified Mann-Kendall trend test for autocorrelated data. Journal of Hydrology, 204(1-4): 182-196.

Kadioglu M, 1997. Trends in surface air temperature data over Turkey. International Journal of Climatology, 17(5): 511-520.

Kahya E, Kalayci S, 2004. Trend analysis of streamflow in Turkey. Journal of Hydrology, 289(1-4): 128-144.

Karaca M, Anteplioglu U, Karsan H, 1995. Detection of Urban Heat-Island in Istanbul, Turkey. Nuovo Cimento Della Societa Italiana Di Fisica C-Geophysics and Space Physics, 18(1): $49-55$.

Kendall M, 1975. Rank Correlation Methods, London: CharlesGriffin.

Khaliq MN, Ouarda TBMJ, Gachon P, Sushama L, St-Hilaire A, 2009. Identification of hydrological trends in the presence of serial and cross correlations: A review of selected methods and their application to annual flow regimes of Canadian rivers. Journal of Hydrology, 368(1-4): 117-130.

Kumar V, Jain SK, Singh Y, 2010. Analysis of long-term rainfall trends in India. Hydrological Sciences Journal-Journal Des Sciences Hydrologiques, 55(4): 484-496.

Mann HB, 1945. Nonparametric tests against trend. Econometrica, 13: $245-259$.

Modarres R, da Silva VDR, 2007. Rainfall trends in arid and semi-arid regions of Iran. Journal of Arid Environments, 70(2): 344-355.

Nasri M, Modarres R, 2009. Dry spell trend analysis of Isfahan Province, Iran. International Journal of Climatology, 29(10): $1430-1438$

Onoz B, Bayazit M, 2003. The Power of Statistical Tests for Trend Detection. Turkish Journal of Engineering and Environmental Sciences, 27: 247-251.

Partal T, Kahya E, 2006. Trend analysis in Turkish precipitation data. Hydrological Processes, 20(9): 2011-2026.
Rashid MM, Beecham S, Chowdhury RK, 2015. Assessment of trends in point rainfall using Continuous Wavelet Transforms. Advances in Water Resources, 82: 1-15.

Saplioglu K, Kilit M, Yavuz BK, 2014. Trend Analysis of Streams in the Western Mediterranean Basin of Turkey. Fresenius Environmental Bulletin, 23(1A): 313-324.

Sonali P, Kumar DN, 2013. Review of trend detection methods and their application to detect temperature changes in India. Journal of Hydrology, 476: 212-227.

Şen Z, 2012. Innovative Trend Analysis Methodology. Journal of Hydrologic Engineering, 17(9): 1042-1046.

Tayanc M, Karaca M, Yenigun O, 1997. Annual and seasonal air temperature trend patterns of climate change and urbanization effects in relation to air pollutants in Turkey. Journal of Geophysical Research-Atmospheres, 102(D2): 1909-1919.

Tecer LH, Cerit O, 2009. Temperature Trends and Changes in Rize, Turkey, for the Period 1975 to 2007. Clean-Soil Air Water, 37(2): 150-159.

Topaloglu F, 2006. Trend detection of streamflow variables in Turkey. Fresenius Environmental Bulletin, 15(7): 644-653.

Toros H, 2012. Spatio-temporal variation of daily extreme temperatures over Turkey. International Journal of Climatology, 32(7): 1047-1055.

Turkes M, 1996. Spatial and temporal analysis of annual rainfall variations in Turkey. International Journal of Climatology, 16(9): 1057-1076.

Turkes M, Koc T, Saris F, 2009. Spatiotemporal variability of precipitation total series over Turkey. International Journal of Climatology, 29(8): 1056-1074.

Turkes M, Sumer UM, Kilic G, 1995. Variations and Trends in Annual Mean Air Temperatures in Turkey with Respect to Climatic Variability. International Journal of Climatology, 15(5): 557-569.

Yenigun K, Gumus V, Bulut H, 2008. Trends in streamflow of the Euphrates basin, Turkey. Proceedings of the Institution of Civil Engineers-Water Management, 161(4): 189-198.

Yerdelen C, Karimi Y, Kahya E, 2010. Frequency Analysis of Mean Monthly Stream Flow in Coruh Basin, Turkey. Fresenius Environmental Bulletin, 19(7): 1300-1311.

Yue S, Wang CY, 2004. The Mann-Kendall test modified by effective sample size to detect trend in serially correlated hydrological series. Water Resources Management, 18(3): 201-218. 